\title{
Climate change, heightened hurricane activity, and extinction risk for an endangered tropical seabird, the black-capped petrel Pterodroma hasitata
}

\author{
T. Hass ${ }^{1, *}$, J. Hyman ${ }^{2}$, B. X. Semmens ${ }^{3}$ \\ ${ }^{1}$ Burke Museum of Natural History and Culture, University of Washington, Seattle, Washington 98195-3010, USA \\ ${ }^{2}$ Department of Biology, Western Carolina University, Cullowhee, North Carolina 28723, USA \\ ${ }^{3}$ Scripps Institution of Oceanography, University of California at San Diego, San Diego, California 92121-2460, USA
}

\begin{abstract}
The destructiveness of major (Category 3 to 5) hurricanes along the United States Atlantic Ocean seaboard has been recognized for centuries. While the effects of hurricanes on coastal ecosystems are well known, the influence of hurricanes on pelagic seabirds is difficult to assess. During the annual Atlantic hurricane season ( 1 June to 30 November), the endangered black-capped petrel Pterodroma hasitata aggregates in Gulf Stream habitats from Florida to North Carolina. On at least 8 occasions over the past century, hurricanes have driven petrels far inland (sometimes as far as the Great Lakes), suggesting the demise of 10s to 100s of individuals. This paper models $>100 \mathrm{yr}$ of data to characterize and compare key aspects of hurricanes that did and did not drive petrels inland. Our model suggests that the predicted increase in the frequency of Category 3 to 5 hurricanes in the region due to climate change could nearly double the expected number of wrecked petrels over the next century and place an endangered species at greater risk of extinction.
\end{abstract}

KEY WORDS: Petrel $\cdot$ Hurricane $\cdot$ Gulf Stream $\cdot$ Climate change $\cdot$ Mortality $\cdot$ Wreck $\cdot$ North Atlantic

Resale or republication not permitted without written consent of the publisher

\section{INTRODUCTION}

On a decadal basis, the 20th century included quiet periods for major hurricanes (1970s, 1980s, and early 1990s) as well as periods of heightened activity (1940s, 1950s, early 1960s, mid-1990s through mid2000s) (Landsea et al. 1999). Recently, global climate models suggest that rising ocean sea-surface temperatures may increase the frequency and intensity of hurricanes in the northwest Atlantic Ocean (Knutson \& Tuleya 2004, Michaels et al. 2006). Models predict that over the next century, major hurricanes are expected to make landfall from Florida to North Carolina at nearly double their historical rates (Bender et al. 2010, Turner 2011), with some observations suggesting that such a change has already occurred (Trenberth 2005, Mann et al. 2009).
For more than a century, ornithologists have noted seabirds displaced inland following major hurricanes (Saffir-Simpson Wind Scale Categories 3 to 5) that struck the eastern seaboard of the United States (e.g. Lindahl 1899, Allen 1904, Murphy 1936). Over the past $30 \mathrm{yr}$, with a notable increase in the number and strength of tropical cyclones in the North Atlantic (Emanuel 2005, Webster et al. 2005), 1000s of coastal and pelagic seabirds, comprising $>40$ species, have been killed or observed far inland by such storms (e.g. Fussell \& Allen-Grimes 1980, Brinkley et al. 1997). Over the past $110 \mathrm{yr}$, dozens of displaced and dead black-capped petrels Pterodroma hasitata (BCPE), an endangered species (IUCN 2010), including 27 specimens found in the United States and 21 in southern Canada (Kaufman 1990, Curry 1996, Brinkley et al. 1997) have been documented (Table 1). 
Table 1. Pterodroma hasitata. Major hurricanes making landfall north of Florida (1893 to 2003) with total count of blackcapped petrel carcasses. (Dead or moribund petrels corroborated by photograph, specimen, or description. Does not include live petrels seen inland that may have died later.) Cape Verde refers to origination east of $36^{\circ} \mathrm{W}$. Strength of hurricanes uses the Saffir-Simpson wind scale. Recurved refers to the hurricane's distance from the coast upon turning north in units of hurricane-force winds (62.5 nautical miles) - higher positive numbers indicate farther offshore

\begin{tabular}{|c|c|c|c|c|c|c|c|c|c|c|}
\hline Year & $\begin{array}{l}\text { Hurricane } \\
\text { name }\end{array}$ & $\begin{array}{l}\text { Cape } \\
\text { Verde }\end{array}$ & $\begin{array}{c}\text { Origin } \\
\left.\text { (long., }{ }^{\circ} \mathrm{W}\right)\end{array}$ & $\begin{array}{c}\text { Landfall } \\
\text { month }\end{array}$ & $\begin{array}{l}\text { Landfall } \\
\text { lat. }\left({ }^{\circ} \mathrm{N}\right)\end{array}$ & $\begin{array}{c}\text { Max. } \\
\text { strength }\end{array}$ & $\begin{array}{l}\text { Landfall } \\
\text { strength }\end{array}$ & $\begin{array}{l}\text { Landfall } \\
\text { angle }\left({ }^{\circ}\right)\end{array}$ & $\begin{array}{l}\text { Recurved } \\
\text { (radii) }\end{array}$ & Carcasses \\
\hline 1893 & Sea Islands (No. 6) & Yes & 20 & Aug & 32 & 3 & 3 & 45 & -1 & 5 \\
\hline 1898 & No. 7 & No & 58 & Oct & 30 & 4 & 3 & 90 & -7 & 3 \\
\hline 1933 & Chesapeake Potomac & No & 48 & Aug & 36 & 3 & 2 & 135 & -2 & 1 \\
\hline 1938 & New England & Yes & 22 & Sep & 41 & 5 & 3 & 90 & 9 & 1 \\
\hline 1955 & Connie & Yes & 36 & Aug & 35 & 4 & 2 & 180 & 0 & 1 \\
\hline 1989 & Hugo & Yes & 20 & Sep & 33 & 5 & 4 & 90 & -6 & 9 \\
\hline 1996 & Fran & Yes & 21 & Sep & 34 & 3 & 3 & 90 & -7 & 26 \\
\hline 2003 & Isabel & Yes & 31 & Sep & 35 & 5 & 2 & 90 & -9 & $\begin{array}{c}2 \\
\text { Total }=48\end{array}$ \\
\hline
\end{tabular}

With an estimated breeding population of 1000 to 2000 pairs (Lee 1999, Brooke 2004), the susceptibility of BCPE to major hurricanes is of concern.

Here, we tested the hypothesis that the effects of climate change-operating through the frequency and intensity of Atlantic tropical cyclones-could further threaten this species. To test this hypothesis, we examined $110 \mathrm{yr}$ of hurricane data and modeled the attributes of hurricanes that caused - and did not cause-observed mortality of BCPE. Through this modeling, we: (1) described the critical characteristics of hurricanes that threaten $\mathrm{BCPE}$ and (2) quantified the potential consequences of climate change and heightened hurricane activity on the population of this species over the coming century.

\section{MATERIALS AND METHODS}

We conducted an exhaustive search of museum collections and literature for storm-wrecked specimens of black-capped petrel Pterodroma hasitata. Because the species is strictly pelagic, it was relatively easy to link specimens to particular tropical cyclones. Where feasible, we attempted to determine the age of wrecked birds, in order to consider effects of mortality on population dynamics.

\section{Specimen and tropical cyclone data}

The disposition of BCPE carcasses salvaged between 1893 and 2003 was largely derived from: the ORNIS data portal (http://ornisnet.org; accessed on August 31, 2011) and the Canadian Biodiversity Information Facility, which are national catalogs of ornithological holdings in museums. We also re- viewed seasonal sightings summarized in the regional reports of 'North American Birds' and predecessor journals. We then made direct communication with collection managers and/or curators from the following museums where specimens of the species were known (or suspected) to reside: American Museum of Natural History, New York, NY; Birdcraft Museum, Fairfield, CT; Buffalo Museum of Science, Buffalo, NY; Canadian Museum of Nature, Gatineau, QC; Carnegie Museum of Natural History, Pittsburgh, PA; Cornell University-Museum of Vertebrates, Ithaca, NY; Museum of Comparative Zoology, Harvard University, Cambridge, MA; North Carolina Museum of Natural Sciences, Raleigh, NC; Peabody Museum of Natural History, Yale University, New Haven, CT; Royal Ontario Museum, Toronto, ON; Smithsonian National Museum of Natural History, Washington, $\mathrm{DC}_{i}$ and University of Connecticut Biological Research Collections, Storrs, CT. For each specimen, we requested information on location, date of collection, sex, and age (via molt, skull ossification, and bursa development). We linked each specimen to a specific tropical cyclone based on collection date. All carcasses were found within $3 \mathrm{wk}$ of the associated hurricane's passage (most within 1 to $10 \mathrm{~d}$ ), with the last-salvaged tending to be the most decomposed. Displaced live petrels were seen in Lake Erie, Ontario, for 2 wk following Hurricane Fran (Brinkley et al. 1997), so relatively fresh carcasses could be found for weeks. To assess the ages of wrecked petrels, we evaluated patterns of molt and feather wear (per Imber 1984, Brown et al. 1986). In such cases, the primary criterion to distinguish hatch-year birds from adults (all ages after hatch year) is the uniformly fresh, unworn plumage of juveniles versus the patchwork of crisp and worn feathers characteristic of older birds. 
Table 2. Pterodroma hasitata. Major hurricanes making landfall north of Florida (1893 to 2003) with no associated blackcapped petrel carcasses. Cape Verde refers to origination east of $36^{\circ} \mathrm{W}$. Strength of hurricanes uses the Saffir-Simpson wind scale. Recurved refers to the hurricane's distance from the coast upon turning north in units of hurricane-force winds (62.5 nautical miles) — higher positive numbers indicate farther offshore

\begin{tabular}{|c|c|c|c|c|c|c|c|c|c|}
\hline Year & $\begin{array}{l}\text { Hurricane } \\
\text { name }\end{array}$ & $\begin{array}{l}\text { Cape } \\
\text { Verde }\end{array}$ & $\begin{array}{c}\text { Origin } \\
\left.\text { (long., }{ }^{\circ} \mathrm{W}\right)\end{array}$ & $\begin{array}{l}\text { Landfall } \\
\text { month }\end{array}$ & $\begin{array}{l}\text { Landfall } \\
\text { lat. }\left({ }^{\circ} \mathrm{N}\right)\end{array}$ & $\begin{array}{l}\text { Max. } \\
\text { strength }\end{array}$ & $\begin{array}{l}\text { Landfall } \\
\text { strength }\end{array}$ & $\begin{array}{l}\text { Landfall } \\
\text { angle }\left({ }^{\circ}\right)\end{array}$ & $\begin{array}{l}\text { Recurved } \\
\text { (radii) }\end{array}$ \\
\hline 1893 & No. 4 & Yes & $36^{\circ}$ & Aug & 41 & 3 & 1 & 135 & 4 \\
\hline 1893 & No. 9 & Yes & $25^{\circ}$ & Oct & 33 & 3 & 3 & 0 & 1 \\
\hline 1896 & No. 2 & No & $59^{\circ}$ & Sep & 42 & 3 & 1 & 90 & 10 \\
\hline 1899 & San Ciriaco & Yes & $31^{\circ}$ & Aug & 35 & 4 & 4 & 60 & 4 \\
\hline 1916 & No. 2 & No & $52^{\circ}$ & Jul & 33 & 3 & 1 & 180 & 7 \\
\hline 1916 & No. 4 & No & 71 & Jul & 33 & 3 & 2 & 90 & -3 \\
\hline 1933 & No. 13 & No & $58^{\circ}$ & Sep & 35 & 3 & 2 & 180 & 0 \\
\hline 1944 & Great Atlantic & No & $58^{\circ}$ & Sep & 41 & 4 & 2 & 135 & 2 \\
\hline 1954 & Hazel & No & $59^{\circ}$ & Oct & 34 & 4 & 4 & 135 & 0 \\
\hline 1955 & Diane & No & $43^{\circ}$ & Aug & 34 & 3 & 1 & 90 & -3 \\
\hline 1955 & Ione & No & $43^{\circ}$ & Sep & 35 & 3 & 1 & 135 & -3 \\
\hline 1959 & Gracie & No & $68^{\circ}$ & Oct & 32 & 4 & 3 & 90 & 8 \\
\hline 1961 & Esther & Yes & $32^{\circ}$ & Sep & 44 & 4 & 0 & 135 & 9 \\
\hline 1969 & Gerda & No & $77^{\circ}$ & Sep & 45 & 3 & 2 & 135 & 18 \\
\hline 1976 & Belle & No & $73^{\circ}$ & Aug & 41 & 3 & 1 & 90 & 11 \\
\hline 1979 & David & Yes & $36^{\circ}$ & Sep & 31 & 5 & 1 & 135 & -1 \\
\hline 1984 & Diana & No & $77^{\circ}$ & Sep & 34 & 4 & 1 & 45 & 3 \\
\hline 1985 & Gloria & Yes & $24^{\circ}$ & Sep & 41 & 4 & 1 & 180 & 4 \\
\hline 1991 & Bob & No & $75^{\circ}$ & Aug & 41 & 3 & 2 & 180 & 5 \\
\hline 1996 & Bertha & Yes & $34^{\circ}$ & Jul & 34 & 3 & 2 & 135 & 3 \\
\hline 1998 & Bonnie & No & $48^{\circ}$ & Aug & 34 & 3 & 2 & 180 & 2 \\
\hline 1999 & Floyd & No & $46^{\circ}$ & Sep & 34 & 4 & 2 & 135 & 3 \\
\hline
\end{tabular}

\section{Predicting wrecks based on storm characteristics}

Because not all storms produced specimens of BCPEs (i.e. 'wrecks'), we compared characteristics of storms that resulted in wrecks with those that did not. Information on the path, strength, and timing of tropical cyclones was obtained through internet archives (www.nhc.noaa.gov/pastall.shtml). All attributes of hurricanes summarized in Tables 1 \& 2 (hurricane name, maximum strength, etc.) were derived from NOAA data. Using model selection, we fitted data on the occurrence/non-occurrence of wrecks resulting from major storms (Category 3 or greater) off the eastern seaboard between 1893 and 2003. During this time, there were a total of 30 major landfalling hurricanes, of which 8 produced wrecks (Fig. 1, Table 1). Of these, 6 were 'Cape Verde' hurricanes that originated east of $36^{\circ} \mathrm{W}$. Seven of the 8 storms struck the coast directly (only 1 collided with the coastline at an angle of $<45^{\circ}$ or $>135^{\circ}$ ), and all made landfall as Category 2 storms or greater. Hurricanes that had nearly parallel paths to the coastline (i.e. landfall angles that were very acute or obtuse) seldom produced mortality or inland petrels (Table 2). From these observations, we generated a candidate set of models with stormspecific occurrence/non-occurrence of wrecks as a binomial response (logit link) and, fixed effects of Cape
Verde classification (categorical), month (continuous), landfall strength (categorical), recurvature (categorical), latitude at landfall (continuous), landfall angle (continuous), maximum storm strength (categorical), and radii at recurve (continuous). Maximum hurricane-force winds generally extend 62.5 nautical miles (n miles; $\sim 115.75 \mathrm{~km}$ ) from the center of a storm (also termed the 'strike circle'); therefore, to quantify how far from the coast a hurricane turned north (recurved), we used the number of hurricane-force wind radii as the unit of measure-with higher positive numbers indicating farther offshore and lower negative numbers signifying turns occurring farther inland. Using StepAIC (a library for the R statistical package) we identified a set of 4 model formulations that resulted in the greatest parsimony, and then calculated the model weights of these models based on their Akaike's information criterion (AIC) scores (Table 3).

\section{Simulating future wrecks}

In order to simulate the expected number of petrel mortalities due to storms over the next 100 yr, we: (1) generated 100000 random draws of integers from a Poisson distribution fitted to data on the number of yearly storm occurrences between 1893 and 2003, 


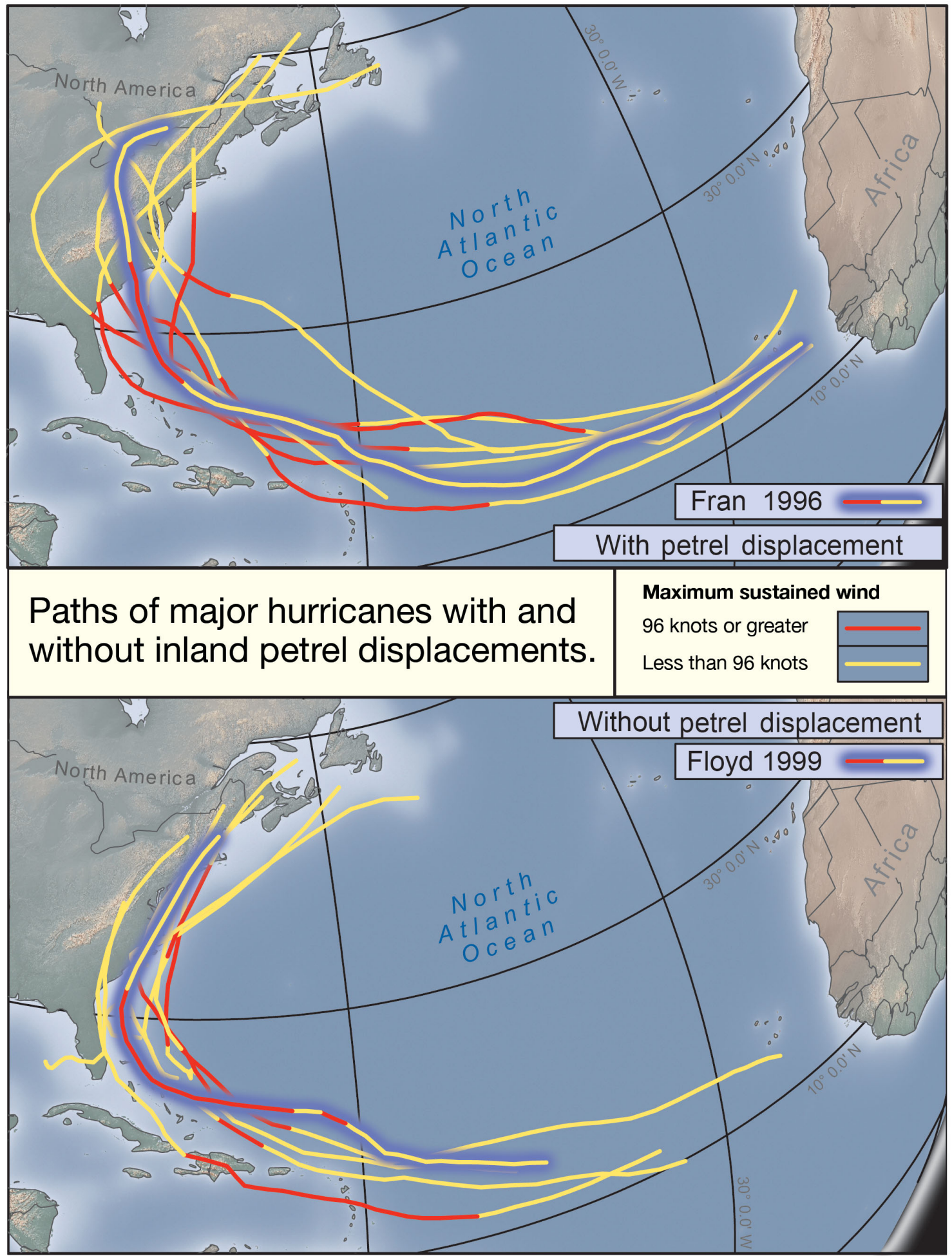

Fig. 1. Pterodroma hasitata. Top: paths of all major landfalling hurricanes (1893 to 2003) that displaced black-capped petrels inland exhibit origins near Cape Verde and strike the coast before recurving. Highlighted path is that of Hurricane Fran (1996), a typical storm-track for this category. Bottom: paths of all major landfalling hurricanes (1960 to 2003 only) that did not displace black-capped petrels show more westward origins and recurving trajectories than those producing petrel specimens. Highlighted path is that of Hurricane Floyd (1999), a typical storm-track for this category. Key characteristics (e.g. maximum strength, landfall date, etc.) for each hurricane are summarized in Tables 1 \& 2. Map generated using NOAA Coastal Services Center data (http://csc-s-maps-q.csc.noaa.gov/hurricanes/viewer.html) 
Table 3. Pterodroma hasitata. Goodness-of-fit models and scores of Akaike's information criterion (AIC). Variables include: whether a Cape Verde-type hurricane (VERDE), latitude at landfall (LANDFALL_LAT), strength at landfall (LAND_ STRENGTH), distance from coast when hurricane turned north (RECURVE_RAD), maximum hurricane strength (MAX_ STRENGTH), angle of hurricane landfall along coast (ANGLE), and month of landfall (MONTH)

\begin{tabular}{|c|c|c|c|}
\hline Model formulation & $\mathrm{AICc}$ & $\Delta \mathrm{AICc}$ & Weight \\
\hline VERDE + LANDFALL_LAT + LAND_STRENGTH + RECURVE_RAD & 25.03 & 0 & 0.49 \\
\hline VERDE + LANDFALL_LAT + MAX_STRENGTH + LAND_STRENGTH + RECURVE_RAD & 25.93 & 0.9 & 0.31 \\
\hline $\begin{array}{l}\text { VERDE + MONTH + LANDFALL_LAT + MAX_STRENGTH + LAND_STRENGTH + } \\
\text { RECURVE_RAD }\end{array}$ & 27.46 & 2.43 & 0.14 \\
\hline $\begin{array}{l}\text { VERDE + MONTH + LANDFALL_LAT + MAX_STRENGTH + LAND_STRENGTH + } \\
\text { ANGLE + RECURVE_RAD }\end{array}$ & 29.825 & 4.22 & 0.06 \\
\hline
\end{tabular}

(2) re-sampled the coefficient values for the models in Table 3 with replacement using storm data between 1893 and 2003, and (3) generated random draws from a log-normal distribution fitted to data on the number of BCPEs present off the eastern seaboard based on monthly boat-based transects between July and September (month included as a continuous effect). For 100000 simulations, annual mortality in each of the next 100 yr based on simulated storm occurrences for each year (based on random draws in 1 above), their likelihood of causing wrecks (based on the coefficient draws in 2 above), and the number of birds wrecked (based on random draws in 3 above) was derived. The likelihood that storms caused wrecks was calculated based on model averaging (Table 3). In other words, we used predictions from each model in proportion to their model weights. To evaluate the overall model fit within the candidate model set used, we conducted a receiver-operating characteristic (ROC) analysis to assess the sensitivity and specificity of the model with the lowest AIC score (Fig. 2). The area-underthe-curve score (true positive rate) of 0.943 resulting from this analysis suggests that our candidate model set was well specified.

\section{Predicting hurricanes from climate change}

Recent stochastic and dynamic climate models predict a slight increase in the intensity of future North Atlantic hurricanes ( 7 and 10.3\%, Turner 2011 and Emanuel et al. 2008, respectively), largely due to the increased genesis of long-lived and powerful Cape Verde hurricanes (Knutson et al. 2010). Bender et al. (2010) anticipate that landfall rates for Category 4 to 5 hurricanes will increase $10 \%$ per decade over the next century-doubling their incidence by 2100 . Similarly, Turner (2011) forecasts that Category 3 to 5 hurricanes will nearly double in landfall frequency between 2011 and 2015 and that continued 'warm scenario' conditions will promote increased genesis of Cape Verde hurricanes. Consequently, we integrated a $1 \%$-per-year increase in the incidence of major hurricanes over the next 100 yr to our model.

\section{RESULTS}

\section{Wrecked petrels}

In the literature and museum records, we located at least 82 inland records of black-capped petrels Pterodroma hasitata (1893 to 2003) associated with the passage of tropical cyclones that were classified as 'major' (Saffir-Simpson Categories 3 to 5) during some point in their development. No petrel carcasses were recovered after a major (or minor) hurricane made landfall in Florida, so we restricted our analysis to hurricanes that came ashore north of Florida (Tables 1 \& 2). Petrels have occasionally been seen

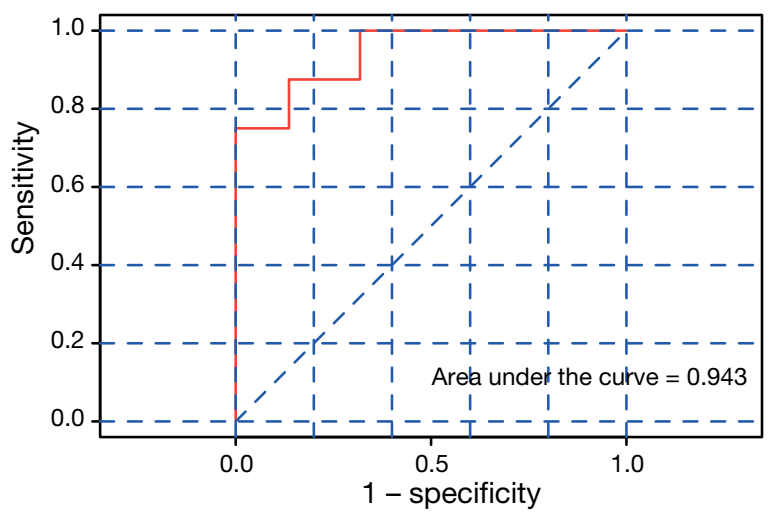

Fig. 2. Plot of the relationship between true positive (sensitivity; $y$-axis) and false positive rate ( 1 - specificity; $x$-axis) based on the parameters derived from the model with the lowest score of Akaike's information criterion (AIC) identified in Table 3. The area under the curve term indicates the true positive rate resulting from the model prediction 
from shore during smaller (Categories 1 to 2 maximum) hurricanes. So far, however, none of the smaller magnitude storms have displaced petrels inland or resulted in mortality (based on museum holdings). For instance, although 3 petrels were seen from shore in North Carolina following the landfall of Category 1 Hurricane Ophelia in 2005, no dead petrels were reported (Dinsmore \& Farnsworth 2006). Since minor hurricanes and tropical storms do not appear to be significant mortality agents, we have excluded such records from our analysis. Of the 82 sight records of inland BCPEs, 48 were substantiated by a bird-in-the-hand. The present study concentrated only on the most recent carcass material, from 1989-2003, or 37 total specimens, because birds salvaged in recent decades tended to have more consistent data recorded for molt, sex, and body condition.

The Carnegie Museum of Natural History prepared 2 skins of BCPEs associated with Hurricane Hugo (1989) and another after Hurricane Fran (1996); all 3 showed evidence of molt in rectrices or contour feathers, strongly suggesting they were adult birds. Birds only a few months past fledging would almost certainly not be in active molt of rectrices (Imber 1976, Warham 1996). Also associated with Hurricane Fran, 8 petrels stored at the Royal Ontario Museum (ROM) showed evidence of molt and were categorized as adults. Only 4 of those 8 individuals were salvaged in good enough condition to allow evaluation of the bursa of Fabricius. None had a bursa, confirming their status as likely breeding-age adults (Broughton 1994). Furthermore, of the 8 intact skulls among the ROM specimens, all showed full ossification (i.e. fusion) of the frontal/prefrontal bones, confirming their ages as after hatch-year (Harper 1978). Two Smithsonian specimens wrecked by Hugo were molting females, but 1 of them had a bursa, indicating that it was greater than 1 yr old but likely of prebreeding age. At the Cornell University Museum of Vertebrates, the 2 petrels salvaged after Fran have uniformly fresh plumage, and were categorized as hatch-year birds. Thus, in our sample of 15 specimens, adult birds outnumbered young (probable yearlings) birds by a ratio of 13:2. This adult bias is not surprising given that the ratio of adult to hatchyear birds collected at sea off North Carolina is 56:3 (T. R. Simons et al. unpubl. data). While males outnumber females by a ratio of 2:1 in those specimens (not 9:1 as reported by Lee 1999), we found that among the 13 wrecked petrels for which sex could be determined, an opposite sex ratio was apparent (5 males:8 females). Although our model is based on deaths of individuals, it assumes a 50:50 sex ratio.

\section{Mechanism of displacement}

A direct path toward the coast is key to whether a hurricane wrecks petrels or not (Tables 1 \& 2). We hypothesize that when west-approaching hurricanes recurve (turn north to northeast) north of Florida, the flight space and prevailing winds that exist between the storm's perimeter and the coastline serve as a corridor through which birds are funneled to shallower, nearshore waters along the eastern seaboard (Fig. 3). Indeed, on average, hurricanes that did not produce specimens tended to recurve when almost $240 \mathrm{n}$ miles east of the coast, while those producing carcasses pushed inland nearly $180 \mathrm{n}$ miles before turning north (Tables 1 \& 2).

\section{Simulated consequences for breeding population}

The mode value in our simulation (Fig. 4) suggests that over the next century, in the absence of climate change, landfalling hurricanes would most likely kill approximately 437 petrels. Because of the preponderance of adults among the wrecked specimens $(>80 \%)$ and in the population at sea off the southeastern United States (95\%), this represents an anticipated loss of at least 415 breeders - or $10.4 \%$ of the 4000 individuals estimated in the current breeding population. About $7 \%$ of the simulations result in
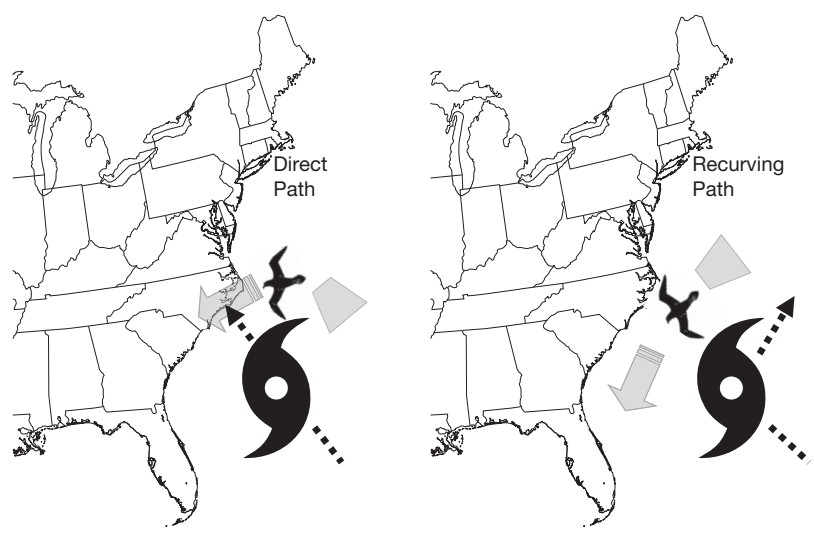

Fig. 3. Pterodroma hasitata. Mechanism of black-capped petrel inland displacement or non-displacement by hurricanes. On average, landfalling major hurricanes that did not produce specimens turned north (recurved) when $>240$ nautical miles offshore, while petrel-producing hurricanes turned north after pushing 180 nautical miles inland. When North Atlantic hurricanes recurve, the extra over-water flight space that is created between the storm's perimeter and the coastline serves as a corridor through which petrels are funneled to shallower, nearshore waters. When hurricanes make landfall on a direct course, no such corridor is created and petrels are swept inland 


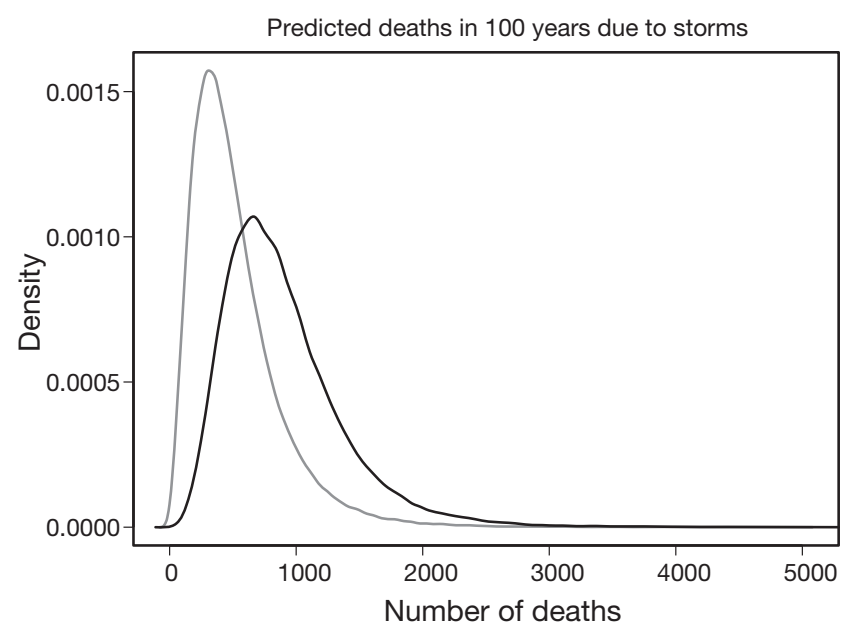

Fig. 4. Pterodroma hasitata. Predicted deaths of black-capped petrels in $100 \mathrm{yr}$ due to storms. If the hurricane activity over the next century is similar to that over the last century, across 100000 simulations, the median cumulative number of deaths of black-capped petrels is 437 (grey line). The chance that $>1050$ (or one-quarter of the estimated breeding population) will die is $7 \%$. If the rate of major landfalling hurricanes rises $1 \%$ annually due to climate change (doubling over the next century as predicted), the median cumulative mortality is 807 petrels (black line), with a $3 \%$ chance that 2100 individuals (half the breeding population) would die due to hurricanes

mortality of $>1050$ individuals (or 1000 breeders) which would reduce the extant breeding population by $25 \%$. If the rate of major landfalling hurricanes increases by an annual rate of $1 \%$ due to climate change (Bender et al. 2010, Turner 2011), doubling by the end of this century, the median cumulative mortality is 807 petrels, with a $3 \%$ chance that 2100 individuals would die due to hurricanes. However, though some estimate the breeding population to be 4000 individuals (Brooke 2004, Keith 2009), Lee argued more than a decade ago (Lee 1999, 2000) that the number of breeders was only 1200 to 2600 individuals - which would put the entire breeding population at risk of extinction if the cumulative mortality exceeds 1200 over the next century.

\section{DISCUSSION}

\section{Considerable direct mortality from hurricanes has occurred over the past century}

Over the last 2 decades, the documented hurricane mortality of black-capped petrels Pterodroma hasitata has totaled $>30$ individuals, although many of the additional 50 individuals observed far inland were probably weakened birds that also perished. Considering the vast areas of ocean and land that these storms affect, along with the relative dearth of people who actively seek hurricane-displaced seabirds (and even smaller number engaged in specimen salvage), the total number of BCPEs killed by hurricanes is certainly far greater than that documented by museum specimens. By systematically surveying a subset of shorelines around Lake Erie and Lake Ontario, Curry (1996) conservatively estimated that for every specimen salvaged or seen dead/floating but unretrieved ( $\mathrm{n}=23$ ), an additional 2 petrels were killed but not found, bringing the total regional mortality to about 70 birds. At least 7 BCPEs were recovered after Hurricane Hugo, and Kaufman (1990) asserted that many times that number must have been killed by the storm. After both hurricanes Hugo and Fran, petrels not only wrecked on large bodies of water, but also in high, remote terrestrial sites - like mountaintopsthat could not be systematically surveyed (Brinkley et al. 1997).

The loss of 10 s to 100 s of individuals during a single hurricane might not represent a demographic threat to a species with a world population estimated at 2000 breeding pairs (Brooke 2004). However, many climate change models suggest that rising seasurface temperatures in the tropical North Atlantic will lead to future hurricanes that are more intense and/or greater in number (Knutson \& Tuleya 2004, Michaels et al. 2006). Petrels, having evolved in a system of cyclonic activity that is subject to such multi-decadal variability, should perhaps be resilient to normal extremes. However, we propose that their populations, facing numerous other conservation challenges (nest site destruction, introduced predators, direct harvest by humans, etc.) will become increasingly vulnerable to additional decline if the coming decades/centuries continue to show cyclonic activity in the North Atlantic Ocean that is markedly higher than the long-term average (Trenberth 2005).

\section{Petrels frequently aggregate in the likely paths of hurricanes}

During 67 offshore surveys in July to September near Cape Hatteras, between 1992 and 1998, the lead author and Brian Patteson encountered extremely dense concentrations ( $>500$ individuals seen per day) of BCPEs at sea twice ( $3 \%$ of daily counts) and moderately dense concentrations (>150 individuals) 10 times (15\% of daily counts). The species' propensity for aggregation near Cape Hatteras, North Carolina 
(the area of most frequent hurricane landfall in the eastern United States) during the height of the Atlantic tropical storm season is particularly alarming, because moderately and extremely dense aggregations of petrels would be expected to be in the direct path of about 1 in 6 and 1 in 33 major hurricanes approaching Cape Hatteras, respectively. Haney (1987) documented similarly elevated abundances off South Carolina and Georgia, so the chance intersection between a moving hurricane and an aggregation of petrels is not confined to Gulf Stream waters off North Carolina.

\section{Petrel flight tendencies promote vulnerability to displacement}

In the Northern Hemisphere, seabirds to the north of a cyclone would tend to take a westward course when the prevailing winds shift from an easterly to a more northern component (Blomqvist \& Peterz 1984), a behavior that would promote escape from recurving hurricanes. Note that the median size of petrelproducing hurricanes at landfall was Category 3 compared to Category 2 for those without carcasses; the smaller hurricanes would be surrounded by smaller wind fields (narrower radii of hurricane-force winds), broadening the crosswind/tailwind corridor for birds described above. Indeed, Adams \& Flora (2010) recently demonstrated that Pterodroma petrels tend to travel with quartering tailwinds, allowing them to circumnavigate mega-scale high-pressure systems. Such a tendency would tend to disperse birds flying to the south of a hurricane away from the system; while petrels located north and west of the system would be vulnerable to being pushed onshore by large hurricanes making direct landfall. Whereas more than one-quarter of major hurricanes that made landfall north of Florida produced inland petrels, none of the 11 major hurricanes that struck Florida between 1893 and 2003 produced a single petrel specimen. We believe that Florida's narrow, peninsular shape and proximity to the Gulf of Mexico probably provides an opportunity for petrels to escape to the southwest.

Numerous hurricanes have blown BCPEs outside their 'normal' marine range-to colder, continental shelf waters as the storms have progressed northward in latitude (Mörzer Bruyns 1967, Finch 1972, Dinsmore \& Farnsworth 2006). Such observations of multiple petrels along the advancing margins of hurricanes are contrary to the proposition that petrels are likely entrained in the calm eyewall of hurricanes and disperse after landfall (Murphy 1936). Sooty terns Onychoprion fuscatus are also strictly pelagic and appear particularly vulnerable to hurricanedriven displacements (Murphy 1936, Brinkley 1999). Murphy's (1936) description of flocks of sooty terns preceding the arrival of hurricanes in the Lesser Antilles is consistent with the mechanism of displacement for that species and BCPEs witnessed along the east coast of the United States. As the Gulf Stream between Florida and North Carolina appears to represent the principle foraging range for adult BCPEs (Haney 1987), any factor that displaces petrels far from the center of their known range is likely detrimental.

During the Atlantic hurricane season, satellitetracking studies have revealed that the Bermuda petrel Pterodroma cahow, another critically endangered petrel, tends to forage in 2 principal areasnear the Azores, and north and west of Bermuda (Madeiros 2010). Both areas lie within the influence of Cape Verde hurricanes, and, furthermore, these foraging hotspots (used by the species in the nonbreeding season) are located north and west of such advancing hurricanes. Because Bermuda petrels are known to use tailwinds to 'slingshot' around the perimeter of storm systems (Madeiros 2010), the positioning of these key foraging areas is likely to raise the species' vulnerability to being pushed inland as individuals transit downwind.

\section{Persistence of Gulf Stream path during climate change should sustain petrels}

At sea, the BCPE appears to be an obligate of Gulf Stream waters off the southeastern United States and aggregates where deepwater upwelling occurs (Haney 1987, Hass 1997). Hence, any changes in the circulation of the Gulf Stream due to climate change might affect the species. Lynch-Stieglitz et al. (1999) demonstrated that during the last glacial maximum, the strength of Gulf Stream transport was only twothirds of that seen today. While it is difficult to predict how reduced transport in the Gulf Stream might affect the frequency and magnitude of many dynamic sources of upwelling (e.g. meanders and eddies), static upwelling sites, where upwelling is topographically induced (like the Charleston Bump and Cape Hatteras slope) seem likely to persist over time. Several authors have shown that a shutdown of the 'global conveyor belt' is possible during either cold or warm conditions (Alley et al. 1997, Broecker 1997). Although the Gulf Stream is likely to weaken during 
such a thermohaline collapse, its position is merely expected to switch from its present meridional course (heading northeast from Cape Hatteras), to a zonal heading (east from Cape Hatteras) (Matsumoto \& Lynch-Stieglitz 2003, Rossby \& Nilsson 2003). This should preserve the Gulf Stream's path (and processes) in the South Atlantic Bight, in the center of the petrels' pelagic range.

\section{Climate change, human settlement and historic declines of tropical Atlantic petrels}

Olson (1975) previously implicated Pleistocene 'environmental change' and associated shifts in marine productivity as leading to the decline and extinction of Pterodroma rupinarum and 2 other tropical tubenoses on St. Helena Island in the tropical South Atlantic. P. rupinarum bred on St. Helena at a comparable latitude $\left(17^{\circ} \mathrm{S}\right)$ to BCPEs, and the already extinct Jamaica petrel $P$. caribbaea bred in the Caribbean $\left(18^{\circ}\right.$ to $\left.20^{\circ} \mathrm{N}\right)$, but declined markedly during non-glacial times. The final demise of both $P$. rupinarum and $P$. caribbaea coincided with human habitation. Recent conservation efforts for the critically endangered Bermuda petrel $P$. cahow have attempted to shift burrows/colonies to higher ground to minimize vulnerability to sea-level rise, hurricanes, and associated storm surges (Wingate \& Talbot 2003). As their breeding population has grown and offshore surveys have become more frequent, Bermuda petrels have been found regularly in the Gulf Stream off North Carolina (Wingate et al. 1998, Patteson \& Brinkley 2004) during the hurricane season, so it seems likely that someday this species too may appear inland among the wrecked. Because BCPEs breed on remote cliff faces in Hispaniola outside the hurricane season, they are not likely to suffer direct mortality at the nesting grounds - though hurricane-induced mudslides and destruction of vegetation could destroy burrows (Goetz et al. 2011).

\section{Simulated hurricane-related mortality has population-level effects on petrels}

When population viability analyses are used to estimate extinction risk for the long term, they usually account for episodic, but extreme catastrophes (e.g. 100 and $500 \mathrm{yr}$ droughts, floods, etc.) that may lead to population bottlenecks or other adverse demographic effects. If the past century of hurricane data and seabird die-offs is representative of the long term, BCPEs will face a demographic threat from major Atlantic hurricanes for millennia. Much like migratory shorebirds that briefly aggregate at stopover sites, petrels frequently exhibit extreme aggregations in space and time. Thus, on the rare occasion that a petrel aggregation (or a known migratory or foraging hotspot) is in the path of a hurricane (or oil spill, etc.), elevated mortality will likely result.

Data from pelagic surveys suggest that moderate to extreme aggregations of BCPEs occur every $5 \mathrm{~d}$ at sea. Such propensity for aggregation (or flocking) means that a significant fraction of the world's population may be in jeopardy if they have happened to amass in the path of a hurricane that is: Category 3 or greater, on a direct course to make landfall, and arose in the eastern North Atlantic (Table 3). Using the past 110 yr as a baseline, our model suggests that, in the absence of climate change, the most probable scenario is the loss of about $10 \%$ of the estimated breeding population over the next century due to hurricane wrecks. When factoring in climate change-a gradual doubling in the frequency of major landfalling hurricanes - the likeliest mortality is about one-fifth of 4000 breeders. However, 1 in 33 simulations demonstrated a loss of 2000 breeders. Considering that $40 \%$ declines were already witnessed during a 2-decade lull in hurricane activity (Woods \& Ottenwalder 1986), any projections of additional doubledigit reductions are distressing. While the above percentages reflect the relative impacts if the breeding population is 2000 pairs (Brooke 2004, Keith 2009), Lee $(1999,2000)$ asserts that the number of breeders may be as low as 600 to 1300 pairs - which would magnify the proportional effects and produce a small chance that hurricanes might wipe out the entire the breeding population by 2111 . Given that the species is already in rapid decline due to other sources of mortality and shows no signs of above-replacement population growth, the deaths of 2100 individuals (mostly breeders) - solely due to hurricanes-over the next century could either cause or significantly contribute to the species' demise. Since our mortality projections only examine the demographic threat posed by hurricanes, we strongly advocate for a greater understanding and mitigation of other mortality sources if the species is to avoid the risk of a population bottleneck, or worse, extinction.

Acknowledgements. We thank C. Clinton for producing Fig. 3. J. Gerwin and B. Browning shared specimen information and skeletal material for BCPEs from the North Carolina Museum of Natural Sciences. B. Millen and M. Peck of the Royal Ontario Museum, S. Rogers of the Carnegie Museum 
of Natural History, J. Linn of the Buffalo Museum of Science, C. Gebhard of the Smithsonian Museum, M. Gosselin of the Canadian Museum of Nature, and K. Bostwick and C. Dardia of the Cornell University Museum of Vertebrates shared extra information and/or photographs for their institutions' BCPEs. L. Hall of the Western Foundation of Vertebrate Zoology, B. Whan and B. Curry, graciously provided copies of articles not otherwise available in our university libraries or online. J. Bridgman provided graphics design support. Offshore surveys by T.H. were supported by funding from the Biology Department at the University of North Carolina at Chapel Hill and North Carolina Museum of Natural Sciences. B. Patteson and M. Tove chartered the pelagic birdwatching trips and provided T.H. with the opportunity to conduct research at sea off Cape Hatteras. We thank E. Wagner, B. Patteson, N. Brinkley and 3 anonymous reviewers for providing useful comments on early versions of the manuscript.

\section{LITERATURE CITED}

Adams J, Flora S (2010) Correlating seabird movements with ocean winds: linking satellite telemetry with ocean scatterometry. Mar Biol 157:915-929

Alley RB, Mayewski PA, Sowers T, Stuiver M, Taylor KC, Clark PU (1997) Holocene climatic instability: a prominent, widespread event 8200 yr ago. Geology 25:483-486

Bender MA, Knutson TR, Tuleya RE, Sirutis JJ, Vecchi GA, Garner ST, Held IM (2010) Modeled impact of anthropogenic warming on the frequency of intense Atlantic hurricanes. Science 327:454-458

Blomqvist S, Peterz M (1984) Cyclones and pelagic seabird movements. Mar Ecol Prog Ser 20:85-92

Brinkley ES (1999) The changing seasons: low pressure. North Am Birds 53:12-19

Brinkley ES, Hass T, Lockyer J (1997) The storms of '96, Part 1. Field Notes 51:818-829

Broecker WS (1997) Thermohaline circulation, the Achilles heel of our climate system: Will man-made $\mathrm{CO}_{2}$ upset the current balance? Science 278:1582-1588

Brooke M (2004) Albatrosses and petrels across the world. Oxford University Press, Oxford

Broughton JM (1994) Size of the bursa of Fabricius in relation to gonad size and age in Laysan and black-footed albatrosses. Condor 96:203-207

Brown RS, Norman FI, Eades DW (1986) Notes on blue and Kerguelen petrels found beach-washed in Victoria, 1984. Emu 86:228-238

Curry B (1996) Hurricane Fran: September 1996. Birders J 5:283-297

Dinsmore SJ, Farnsworth A (2006) The changing seasons: weatherbirds. North Am Birds 60:14-26

Emanuel K (2005) Increasing destructiveness of tropical cyclones over the past 30 years. Nature 436:686-688

> Emanuel K, Sundararajan R, Williams J (2008) Hurricanes and global warming: results from downscaling IPCC AR4 simulations. Bull Am Meteorol Soc 89:347-367

Finch DW (1972) Northeastern maritime region. Am Birds 26:832

Fussell JO III, Allen-Grimes A (1980) Bird sightings associated with Hurricane David. Chat 44:89-100

Goetz JE, Norris JH, Wheeler JA (2011) Conservation action plan for the black-capped petrel (Pterodroma hasitata). International black-capped petrel conservation group, available at www.fws.gov/birds/waterbirds/petrel/ (accessed January 2012)

Haney JC (1987) Aspects of the pelagic ecology and behavior of the black-capped petrel (Pterodroma hasitata). Wilson Bull 99:153-168

Harper PC (1978) The plasma proteins of some albatrosses and petrels as an index of relationship in the Procellariiformes. NZ J Zool 5:509-548

Hass T (1997) Distributions of pelagic seabirds in relation to dynamic features of the Gulf Stream. PhD dissertation, University of North Carolina, Chapel Hill, NC

> Imber MJ (1976) Breeding biology of the grey-faced petrel Pterodroma macroptera gouldi. Ibis 118:51-64

Imber MJ (1984) The age of Kerguelen petrels found in New Zealand. Notornis 31:89-91

IUCN (International Union for Conservation of Nature) (2010) Pterodroma hasitata. In: IUCN 2011. IUCN Red List of Threatened Species, Version 2011.1, available at www.iucnredlist.org (accessed 7 October 2011)

Kaufman K (1990) The changing seasons. Autumn 1989. Am Birds 44:39-43

Keith A (2009) Hispaniola: Haiti and Dominican Republic, and Navassa Island (US). In: Norton RL, Bradley PE (eds) An inventory of breeding seabirds of the Caribbean. University Press of Florida, Gainesville, FL

Knutson TR, Tuleya RE (2004) Impact of $\mathrm{CO}_{2}$-induced warming on simulated hurricane intensity and precipitation: sensitivity to the choice of climate model and convective parameterization. J Clim 17:3477-3495

Knutson T, McBride J, Chan J, Emanuel K and others (2010) Tropical cyclones and climate change. Nat Geosci 3: 157-163

> Landsea CW, Pielke RA Jr, Mestas-Nuñez AM, Knaff JA (1999) Atlantic Basin hurricanes: indices of climatic changes. Clim Change 42:89-129

Lee DS (1999) Pelagic seabirds and the proposed exploration for fossil fuels off North Carolina: a test for conservation efforts of a vulnerable international resource. J Elisha Mitchell Sci Soc 115:294-315

Lee DS (2000) Status and conservation priorities for blackcapped petrels in the West Indies. In: Schreiber EA, Lee DS (eds) Status and conservation of West Indian seabirds. Special Publication 1, Society of Caribbean Ornithologists, Ruston, LA

Lindahl J (1899) The black-capped petrel (Aestrelata hasitata) on the Ohio River at Cincinnati. Auk 16:75

Lynch-Stieglitz J, Curry WB, Slowey N (1999) Weaker Gulf Stream in the Florida Straits during the last glacial maximum. Nature 402:644-648

Madeiros J (2010) Cahow recovery program. Breeding season report for 2009/2010. Department of Conservation Services, Bermuda Government, available at http:// bermudaconservation.squarespace.com/bermuda-petrelcahow/

> Mann ME, Woodruff JD, Donnelly JP, Zhihua Zhang Z (2009) Atlantic hurricanes and climate over the past 1500 years. Nature 460:880-883

> Matsumoto K, Lynch-Stieglitz J (2003) Persistence of Gulf Stream separation during the last glacial period: implications for current separation theories. J Geophys Res 108(C6):3174. doi:10.1029/2001JC000861

Michaels PJ, Knappenberger PC, Davis RE (2006) Sea-surface temperatures and tropical cyclones in the Atlantic basin. Geophys Res Lett 33:L09708. doi:10.1029/2006GL 025757 
Mörzer-Bruyns WFJ (1967) Black-capped petrels (Pterodroma hasitata) in the Atlantic Ocean. Ardea 55:270

Murphy RC (1936) Oceanic birds of South America. Macmillan and American Museum of Natural History, New York, NY

Olson SL (1975) Paleornithology of St. Helen Island, South Atlantic Ocean. Smithson Contrib Paleobiol 23:1-49

Patteson JB, Brinkley ES (2004) A petrel primer: the gadflies of North Carolina. Birding 36:586-596

Rossby T, Nilsson J (2003) Current switching as the cause of rapid warming at the end of the last glacial maximum and younger Dryas. Geophys Res Lett 30:1051. doi: 10.1029/2002GL015423

Trenberth K (2005) Uncertainty in hurricanes and global warming. Science 308:1753-1754

Turner JK (2011) Regional increases in landfall frequency and intensity of Atlantic hurricanes in a stochastic model forecast. In: Lupo A (ed) Recent hurricane research-

Submitted: March 30, 2011; Accepted: March 14, 2012 climate, dynamics, and societal impacts. InTech, available at www.intechopen.com/books/recent-hurricaneresearch-climate-dynamics-and-societal-impacts

Warham J (1996) The behaviour, population biology and physiology of the petrels. Academic Press, London

Webster PJ, Holland GJ, Curry JA, Chang HR (2005) Changes in tropical cyclone number, duration, and intensity in a warming environment. Science 309: 1844-1846

Wingate DB, Talbot P (2003) Implications of global warming and sea-level rise for coastal nesting birds in Bermuda. In: Pienkowski M (ed) A sense of direction: a conference on conservation in UK Overseas Territories and other small island communities. UK Overseas Territories Conservation Forum, Oxon, p 247-256

Wingate DB, Hass T, Brinkley ES, Patteson JB (1998) Identification of Bermuda petrel. Birding 30:18-36

Proofs received from author(s): April 29, 2012 